\title{
Selling out
}

\author{
Joel F Martin
}

Preferred stock preferences bite into an entrepreneur's returns. What can you do to put venture capitalists on a diet?

\begin{abstract}
t's finally payday! You've spent years building your company, clawed your way through financing after financing, and perhaps suffered the slings and arrows of risky, expensive clinical trials. Now a large pharmaceutical company has offered to buy you out. It has taken more money and time than expected, but you and your team still own a respectable percentage of the company, so it's time to open the champagne!

This is when your trusted corporate counsel pulls you aside for a little talk. "You see," she or he says, "there is ownership and there's ownership, and they aren't equal." Your attorney is talking about the types of stock owned by employees (common stock) and investors (preferred stock) and the differences between the two.

On the basis of my own experiences as a venture capitalist, investors always understand these differences; entrepreneurs almost never do. In this article, I explain the differences and how to prepare your company (and yourself) for the best possible outcome.
\end{abstract}

\section{Forewarned is forearmed}

Especially in today's difficult fund-raising environment, companies may be forced to accept stringent terms to attract capital, and that means more money for investors and less money for you at exit. Back when the initial public offering (IPO) market was hot, the differences between classes of stock were modest and could often be ignored. That's because investors are forced to convert to common stock as part of an IPO and all of the preferential treatment accorded to preferred stock disappears. But today, IPOs are rare and acquisition is the preferred route of exit. This creates complex layers of expensive stock preferences, and this is bad news for founders.

There are two key financial preferences that differentiate the payouts between common and

Joel F. Martin is president and CEO of Altair Therapeutics, San Diego, California, USA. e-mail:jfmartin@altairthera.com

\section{Box 1 The rights of investors}

Almost all venture capital financings contain at least one liquidation preference. The main types of these deal terms are liquidation rights and participation rights. The former gives the preferred shareholders the right to get their money back first in the event of the sale, merger or winding down of a company. This preference can have a multiplier that ranges from zero to several times the invested amount. In contrast, a participation right enables preferred shareholders (investors) to continue to collect their respective 'ownership' of the remaining proceeds alongside the common shareholders, even after they have claimed their liquidation preferences. The participation right can be capped at a specific multiple or can be unlimited.

A comparatively innocuous set of terms is a liquidation preference that allows investors to get their money back first with no subsequent participation rights. Under those terms, investors simply take the larger of two options - either getting their money back or converting to common stock and taking their respective ownership percentage.

A more punishing extreme, formerly imposed on companies in trouble and now more broadly, occurs when investors get a multiple of their capital back first and then get their percentage on top of that.

preferred shareholders (Box 1). The first is the liquidation preference, and the second is the participation right.

There are good reasons why preferences exist. Consider the simple case in which investors pay $\$ 10$ million for a $50 \%$ ownership stake in a company. Suppose that the company is then sold for \$10 million. On a pure ownership basis, the common shareholders (namely, management and founders) and the investors would each receive $\$ 5$ million, resulting in a $\$ 5$ million gain for common shareholders and a $\$ 5$ million loss for investors. Here, wealth is simply transferred to management. Investors guard against this through liquidation preferences that guarantee that they get their money back before anyone else gets a penny.

Today, liquidation preference multiples greater than one are increasingly common, particularly in later-stage financings. This means that investors get back a multiple on their investment before money goes to common shareholders. In high-tech financings, such multiples are being imposed as early as first rounds, and biotech terms may not be far behind. Sometimes, investors receive two or three times their investment, or even higher multiples, before common shareholders receive any proceeds whatsoever.

There's a similar trend in participation rights, with $64 \%$ of all financings having full participation, providing investors with unlimited participation in the gains (Box 1).

High liquidation multiples are common in venture capital 'bridge loans', which are usually put in place to bridge a company to an equity financing, a merger or an acquisition transaction. If sold while the loan is in place-not an unusual happenstance-the company's liquidation preferences come into play and the investors enjoy an up-front multiple on their investment. Call options (referred to as warrants) further increase the returns to the loan investors (Box 2).

There are three things you as an entrepreneur can do to mitigate the effect of preferences. First, understand the capital structure of your company and any pending financings. Second, communicate openly with your investors and your board about any inequities, unrealistic terms and disincentives to management. Third, limit 


\section{Box 2 Dividends and warrants}

Some financings provide for cumulative preferred stock dividends of $8 \%-9 \%$ for the preferred shareholders but not for the common shareholders. These dividends effectively increase the liquidation preference multiple over time. With many companies attaining liquidity after seven or more years, such dividends can amount to a liquidation premium of 1.5 times the investment, or more,for some series of preferred stock. Both the layers of preferences and the dividends can make for an unwelcome surprise for a CEO who thinks he faces a liquidation preference that is one times the investment.

Another preferred stock sweetener is called a warrant. It is a type of stock option that allows investors to buy additional stock at a preset price in the future. Warrants are similar to employee stock options but typically have more complex terms. They are frequently imposed in difficult financing situations as a means to boost potential returns to investors. Warrants further dilute common shareholders during a successful exit.

the amount of capital you raise to the minimum needed to get the work done.

\section{Capital structure}

It takes skill and hard work to thoroughly understand capital structures. Entrepreneurs are usually more interested in products and science than financing documents, and laziness may prevail over diligence. Older companies with multiple rounds of financing are particularly hazardous, with a punitive overhang of preferences and payout formulas that run into many pages of complex legalese.

The accumulated preferences can be especially punitive when companies have been through difficult down rounds, known as 'cram down' or 'washout' rounds in the colorful vernacular of venture capitalists. In these rounds, a company's stock price is significantly reduced and the ownership of earlier investors is diluted proportionately. The problem is that venture capitalists leading a washout financing may allow earlier investors (with whom they will be doing future deals) to retain their liquidation preferences to preserve goodwill and discourage retaliation. Alas, the overhanging liquidation preferences can completely wipe out entrepreneurs.

The solution is to understand your capital structure and its ramifications. Start by working with your corporate counsel and an experienced financing expert to build a spreadsheet model. Don't count on your counsel to flag potential problems without prompting. They work with your investors on many deals (compared to your one deal), and they are not looking to bite the hand that feeds them. However, they will walk you through the process if asked-so by all means, ask.

\section{Talk, talk, talk}

If there are inequities in your capital structure, you need to martial your resources and rectify the issues by communicating with your board and investors. Key points to address are comparability to industry norms, adverse incentives to management and fairness. Here a compensation consultant can work wonders in validating appropriate comparables and norms. Remember, your investors want you incentivized to maximize their returns. If your incentives point in the wrong direction, investors should be interested in aligning your interests with theirs. The penalties to investors for not aligning interests can be severe. For example, management may forego an attractive opportunity to be acquired (because of overhanging preferences) in favor of a highly speculative effort to go public (because it wipes out those preferences).

There are several ways to encourage alignment, including appealing to investors' common sense-if there's nothing in it for you, there's likely nothing in it for them. Additionally, incoming investors can be very powerful allies. They have fresh enthusiasm, their preferences are senior to those of the other investors and they have a strong desire to see you motivated. Legacy investors are prone to protecting preferences on investments that may really be sunk costs. Understanding the circumstances and motivations of each set of investors is the key to any capital structure renegotiation. Antagonistic incentives between different classes of investors can produce amazing fireworks at board meetings but will be detrimental to your company if left unresolved.

A variety of mechanisms can be used to align the incentives of investors and management. The most routine is to issue more common stock, though this doesn't solve the problem of overhanging preferences. The second is a carveout provision that sets aside a pot of money for the management. The amount of the carve out is highly variable (for example, $2 \%-10 \%$ or more) depending on the negotiating skill and leverage of management. Carve outs are typically negotiated in the heat of an acquisition, often when management discovers they are getting skunked. Carve outs usually favor the company's most senior management because of their importance in closing the deal. Other employees, and nonemployees such as scientific founders, may be left out. These shareholders then find their payouts diminished not only by the preferred stock preferences but also by the carve out. There are other mechanisms for aligning interests, ranging from a set aside for common shareholders to converting old preferred stock to common stock as part of a new financing.

The worst time to renegotiate a capital structure is when there is an acquisition offer on the table. Management has already done its job and investors are focused on keeping just a few key people that the acquirer wants to retain. Any leverage management had is gone, leading to two deleterious consequences. First, the pot of money set aside for the common stock is minimized. Second, a key person may realize his importance to the deal and subsequently extort a disproportionate piece of the pie. I have seen this happen and can vouch that it causes infighting and tremendous unhappiness, and it can even kill a deal. Generally, the sooner that structural issues are addressed, the better. There are particularly propitious times from a leverage perspective. These include successful times (the negotiation is easier when investors are happy), new financings (when the incoming investors are most aligned with management) and management changeover (when new management has unique leverage in cleaning up structural problems).

\section{Pass on the peas}

The simplest way to mitigate preferences is to obtain a high multiple on invested capital. To get that multiple, you can either increase the numerator (the price) or decrease the denomi-

\section{Table 1 Return on total invested capital ${ }^{\mathrm{a}}$}

\begin{tabular}{lllllll} 
Total invested (millions) & $\mathbf{0 - 2 0}$ & $\mathbf{2 0 - 4 0}$ & $\mathbf{4 0 - 6 0}$ & $\mathbf{6 0 - 8 0}$ & $\mathbf{8 0 - 1 0 0}$ & $>100$ \\
\hline Average investment (millions) & 11.4 & 29.7 & 50.5 & 72.0 & 87.7 & 134 \\
\hline Average return value (millions) & 73.0 & 132.4 & 160.3 & 196.2 & 166.0 & 202.3 \\
\hline Average return multiple & 6.4 & 4.5 & 3.2 & 2.7 & 1.9 & 1.5 \\
\hline Return multiple standard deviation & 2.5 & 3.2 & 2.4 & 1.3 & 0.8 & 0.6 \\
\hline Number of exits & 9 & 15 & 21 & 15 & 10 & 19 \\
\hline
\end{tabular}

aStatistics derived from Booth, B.L. Nat. Biotechnol. 25, 853-857, 2007 and pooled by investment amount rather than return multiple. 
nator (the amount invested). The acquisition price (numerator) is largely beyond your control, but the money you raise (denominator) is not. The trick is capital efficiency. Remember, every dollar taken in financing is a dollar added to overhanging liquidation preferences. Larding up on unnecessary cash inflates not only liquidation preferences but also the 'post-money valuation' of the company, or the company's value after investment. This makes it hard to find an acceptable exit for either the investors or the entrepreneurs.

The notion of taking less money than offered is antithetical to many in biotech. Some luminary first-generation biotech venture capitalists will say that "the time to take the peas is when they are passing the peas." Namely, take the money when it's on the table. That was probably sage advice in the days when biotech was focused on inexpensive research (compared to clinical development) and IPOs were the exit of choice. Today, venture financings are much larger. According to PricewaterhouseCoopers' (New York) MoneyTree Report, the average biotech financing ballooned from $\$ 5.7$ million in 1998 to $\$ 10.8$ million in 2007 (based on the cash infusion per tranche rather than the total round size). Over that period, larger venture fund sizes incentivized investors to put more money to work per financing.

Usually, companies raise prudent sums to support clinical trials or secondary programs that have positive net present value even at the high cost of capital imposed by venture financings. Unfortunately, I've seen many instances in which companies take down too much capital simply because it is available. A company may wish to build a cash cushion, fund excessively speculative projects, build manufacturing infrastructure or simply increase headcount when outsourcing would suffice. Companies may raise capital for early-stage backup programs to mitigate the risk of failure for later-stage lead programs, even when such programs wouldn't justify investment on their own. Sadly, in the event that the first program fails, managementat least the current management anyway-may not be around to advance a second program.

Taking too much cash does a disservice on two counts. The first is the penalty exacted by liquidation preferences as we have discussed. The second is that, historically, more capital correlates with lower multiples on invested cash. Coupled, these two factors can erase much of the economic incentive that has traditionally spurred entrepreneurship.

An inverse correlation between return multiples and increasing capitalization is shown in Table 1. There is a clear take-home message from these data. The return multiples declined from 6.4 times to 1.5 times the investment as
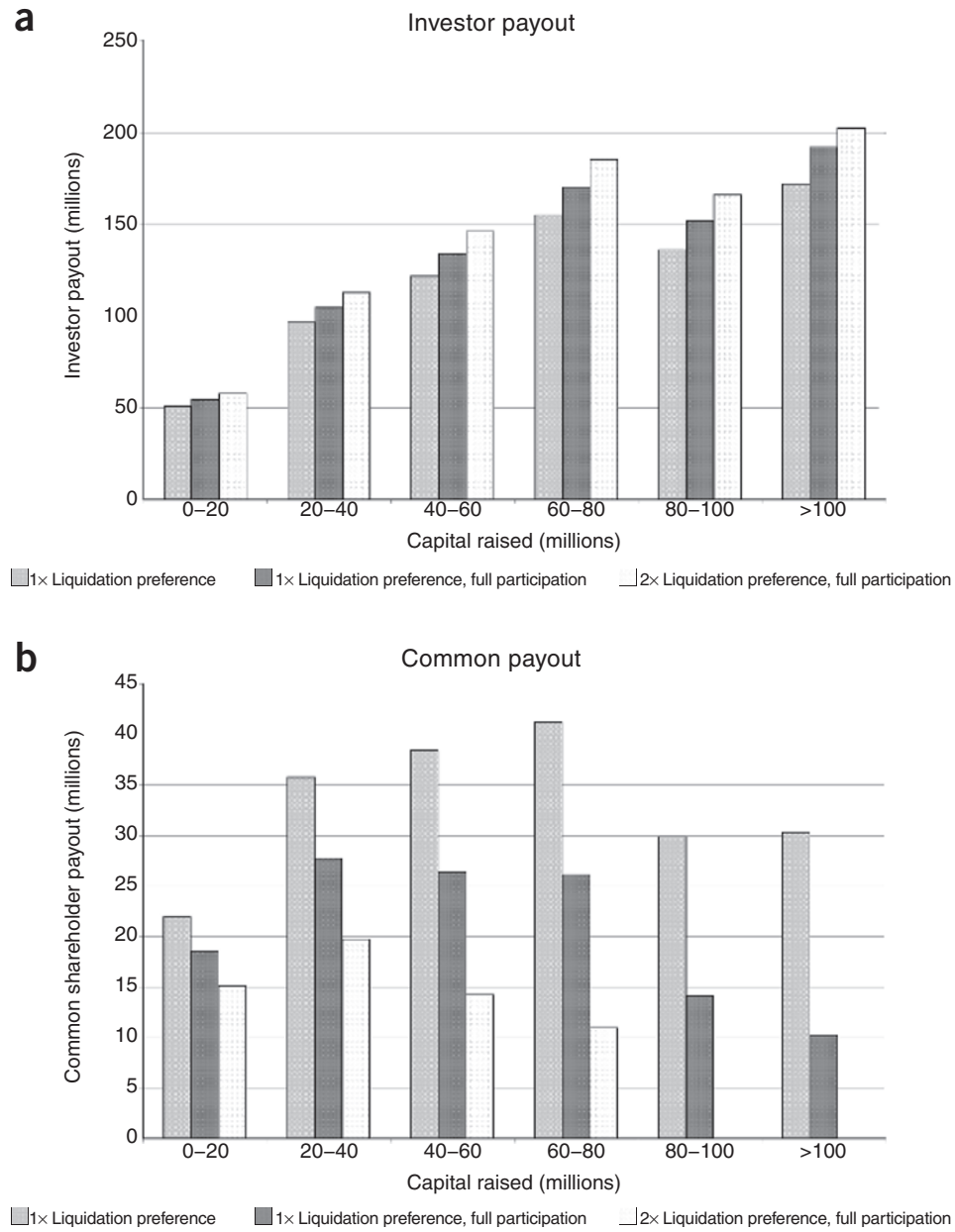

Figure 1 Returns. (a) Investor payout against capital raised. (b) Common shareholder payout against capital raised

the capital raised grew from $\$ 20$ million to $\$ 100$ million. Lower multiples exacerbate all of the problems described above (Fig. 1). (The model explicitly assumes an acquisition in which the preferences come into play.)

Regardless of the specific capital structure, the money returned to common shareholders peaks at less than $\$ 80$ million of invested capital. The more stringent the preference terms, the earlier the peak, even when we ignore all the other things that cut into common shareholder returns (for example, payments to bankers, debt repayment, warrants and cumulative preferred dividends).

The model relies on several assumptions, particularly the tabulated return data and an idealized capital structure. However, it probably understates the problems of raising too much capital. Acquisition prices have dropped sharply in the past year (particularly up-front cash payments), so the model is probably optimistic. The lesson is twofold: first, raise capital prudently with a sober perspective on probable outcomes, and second, if you are coming into a company that has already raised a lot of cash, understand the consequences of the exiting capital structure; it may yet be possible to change the deal.

\section{A balanced meal}

Entrepreneurs need to keep the totality of their businesses in mind. Tough financing terms and large capital requirements interact to punish entrepreneurs for the life of their companies. It's critical to understand what you're getting into and what it means down the road. Oddly enough, it may be better to take a lower valuation and favorable terms than a high valuation and punitive terms. It pays to do the math! Entrepreneurs need to understand the implications of their capital structures and rectify inequities before they become an issue. Furthermore, they need to analyze projects such that they provide positive returns with a cost-of-capital that includes the full burden of preferences. To stay aligned, all shareholder classes should strive for fair, transparent terms, an understanding of the implications of those terms and an eye toward capital efficiency. 10 , 